\title{
Hubungan Kualitas Puasa dan Kebahagiaan Santri Pondok Pesantren Al-Ihsan
}

\author{
Pipih Muhopilah, Witrin Gamayanti, Elisa Kurniadewi \\ UIN Sunan Gunung Djati, Jl. AH Nasution No. 105 Bandung \\ e-mail: pipihmuhopilah7@gmail.com
}

\begin{tabular}{|c|c|}
\hline Abstract / Abstrak & Keywords / Kata kunci \\
\hline $\begin{array}{l}\text { Fasting is one of worship rituals that is usually done by santri, but they have } \\
\text { many activities in boarding school and campus that caused not only positive but } \\
\text { also various negative effects. These effects may lower the productivity and life } \\
\text { satisfaction, and increase negative emotion. This research aims to examine the } \\
\text { relationship of fasting quality and happiness. This study used quantitative method } \\
\text { with the fasting quality scale based on Al-Ghazali's theory and Oxford Happiness } \\
\text { Questionnaire, which is analyzed by Pearson analysis method. Total respondent } \\
\text { for this research is } 150 \text { respondents. The result of this research shows that the } \\
\text { quality of fasting had correlation with santri's happiness, with percentage is } \\
\text { O.466. When fasting santri avoided to do something bad, be more patient, and } \\
\text { tried to do anything according with guidance from Allah that it causes positive } \\
\text { emotion and satisfaction, so they have high quality offasting and happiness. }\end{array}$ & $\begin{array}{l}\text { Fasting } \\
\text { Happiness } \\
\text { Santri }\end{array}$ \\
\hline $\begin{array}{l}\text { Puasa merupakan salah satu ibadah yang sering dilakukan santri, namun } \\
\text { banyaknya kegiatan santri Ponpes Al-Ihsan yang juga seorang mahasiswa } \\
\text { menimbulkan dampak positif maupun negatif. Sehingga produktivitasnya } \\
\text { berkurang dan menjadi kurang puas terhadap kehidupannya serta } \\
\text { menimbulkan emosi negatif. Penelitian ini bertujuan untuk mengetahui } \\
\text { hubungan kualitas puasa terhadap kebahagiaan santri. Penelitian ini } \\
\text { menggunakan metode kuantitatif dengan menggunakan skala kualitas } \\
\text { puasa berdasarkan pendapat Al-Ghazali dan Oxford Happiness } \\
\text { Questionnaire, kemudian dianalisis dengan analisis korelasi Pearson. } \\
\text { Jumlah responden penelitian ini sebanyak } 150 \text { santri. Hasil penelitian ini } \\
\text { menunjukkan adanya hubungan kualitas puasa dengan kebahagiaan santri, } \\
\text { dengan nilai korelasi } 0,466 \text { atau nilai korelasi sedang. Ketika puasa santri } \\
\text { terdorong untuk menghindari berperilaku buruk, senantiasa bersabar, } \\
\text { berusaha berperilaku sesuai dengan kehendak Allah dimana hal ini } \\
\text { mendatangkan emosi positif dan kepuasan sehingga semakin tinggi } \\
\text { kualitas puasanya maka semakin tinggi pula kebahagiaan yang dirasakan. }\end{array}$ & $\begin{array}{l}\text { Puasa } \\
\text { Kebahagiaan } \\
\text { Santri }\end{array}$ \\
\hline
\end{tabular}

\section{Pendahuluan}

Secara umum, santri yaitu orang yang belajar dan mendalami agama Islam di sebuah pesantrian (pesantren) yang menjadi tempat belajar bagi para santri (Departemen Pendidikan dan Kebudayaan, 1998, dalam Megarani, 2010). Pondok pesantren Al-Ihsan merupakan salah satu pondok pesantren yang ada di daerah Cibiru Hilir, Kabupaten Bandung. Letaknya yang dekat dengan kampus membuat santri Al-Ihsan mayoritas adalah mahasiswa UIN SGD Bandung.

Di pondok pesantren Al-Ihsan terdapat berbagai organisasi kesantrian, dari mulai organisasi perasrama, organisasi satu pondok serta organisasi-organisasi yang mengembangkan minat dan bakat santri, dimana setiap santri di bebaskan untuk mengikuti organisasi apapun yang diinginkan. Dengan banyaknya kegiatan santri ini, diasumsikan santri dapat merasakan kegembiraan, hal ini berdasarkan pendapat Diener (1997, dalam Utami, 2009) bahwa kegiatan yang menarik dapat menjadi suplemen kegembiraan individu melalui kenyamanan emosi dan fisik. Menurut Saipudin (2009 dalam Ardiansyah, 2014) mahasiswa memiliki berbagai masalah dalam kehidupannya, masalah-masalah tersebut diantaranya (1) 
pendidikan dan pengajaran; (2) karir dan pekerjaan; (3) ekonomi dan keuangan; (4) diri pribadi, serta (5) agama, nilai dan moralitas, yakni kemampuan melaksanakan tuntutan keagamaan atau kekhawatiran tidak mampu menghindari larangan agama.

Berkenaan dengan tuntutan keagamaan, pondok pesantren Al-Ihsan memfasilitasi para santri untuk dapat memenuhinya, yakni dengan cara memberikan pendidikan keagamaan yang terjadwal dengan baik, memberikan fasilitas berupa tempat beribadah, serta membudayakan pelaksanaan ibadah secara kolektif, sehingga para santri terbiasa untuk melakukan berbagai ritual peribadatan baik ibadah wajib maupun ibadah sunnah.

Berdasarkan studi awal yang dilakukan, salah satu ibadah yang sering dilakukan oleh para santri adalah berpuasa, baik puasa wajib maupun puasa sunnah. Berbeda dengan ibadah lain, puasa adalah ibadah bersifat individual, dimana hanya orang yang melaksanakannyalah yang benar-benar mengetahuinya, dan di pondok pesantren Al-Ihsan ibadah puasa tidak dijadikan salah satu program ibadah yang dibudayakan atau dilakukan secara kolektif. Namun pada 105 santri ponpes Al-Ihsan yang peneliti temui, seluruhnya pernah melakukan puasa, baik puasa wajib maupun puasa sunnah. Saat puasa subjek mengakui merasakan haus, lapar, lemas dan tenang Dari segi perilaku, 89 orang responden menyatakan bahwa ketika puasa responden lebih berusaha untuk mengendalikan dirinya, terutama dari perilaku yang dapat menghilangkan pahala puasa, seperti ghibah, berdusta, bersumpah palsu, memandang dengan nafsu dan marah (Al-Ghazali, 2012).

Penelitian Rosita (2009) menunjukan bahwa dalam puasa terdapat aspek pengendalian diri, karena inti dari puasa adalah pengendalian diri dari hal-hal yang dilarang ketika berpuasa, jadi puasa berisikan latihan kesabaran, latihan ketekunan serta pendidikan bagi hati manusia, puasa sebagai upaya pengendalian diri dari tindakan-tindakan yang merugikan.

Qardawi (2006) mendefinisikan puasa sebagai menahan dan mencegah kemauan dari makan, minum, bersetubuh dengan istri sehari penuh, dari terbitnya fajar siddiq hingga terbenamnya matahari, dengan niat tunduk dan mendekatkan diri kepada Allah SWT (Qardawi, 2006, h. 18).

Dalam Islam shaum berarti menahan diri untuk tidak makan, minum, dan melakukan hubungan seksual sejak waktu subuh hingga magrib. Hal ini disebut dengan puasa lahiriyah. Puasa lahiriyah seperti itu harus dibarengi dengan puasa bathiniyah, yaitu menahan diri dari segala macam hawa nafsu, pikiran yang negatif, serta perbuatan dan perkataan yang tidak baik (Subandi, 2009).

Berdasarkan angket yang telah disebar terhadap 105 santri, 96 responden menyatakan lebih bahagia ketika berpuasa. Hal ini karena ia merasa lebih dekat dengan Allah, lebih bisa mengontrol dirinya, lebih bisa berhemat serta merasa senang ketika waktu berbuka tiba.

Berdasarkan tingkatan puasanya Imam AlGhazali membagi puasa menjadi tiga tingkatan yaitu puasa umum, puasa khusus dan puasa paling khusus. Dengan adanya perbedaan tingkatan dalam berpuasa ini, maka memungkinkan adanya perbedaan perilaku orang-orang yang berpuasa dalam waktu yang sama (AlGhazali, 2012).

Pada tingkatan pertama yaitu puasa umum, orang yang sedang berpuasa mampu menjaga diri dari menahan perut dan kemaluan dari pemenuhan hasrat berupa makan, minum dan bersenggama. Tingkatan yang kedua yaitu puasa khusus, puasa yang didalamnya tidak hanya sekedar menahan diri dari memenuhi keinginan perut serta berhubungan suami istri di siang hari, akan tetapi juga mampu mencegah seluruh anggota badannya dari perbuatan dosa dan maksiat yang meliputi menjaga pendengaran, penglihatan, lisan, tangan, kaki dan anggota tubuh yang lain dari dosa maupun maksiat. Dan pada tingkatan yang ketiga yaitu puasa paling khusus yakni puasa yang dilakukan seseorang dengan ikhlas mengorbankan seluruh jiwa raga serta hartanya untuk mencari keridhoan Allah (Al-Ghazali, 2012). 
Jadi, dapat disimpulkan bahwa puasa pada tingkatan tertinggi mampu menjadikan orangorang mempunyai ruh yang sedemikian rupa sehingga tetap bertahan dengan rasa lapar dan haus, tetap berinteraksi baik dengan masyarakat, dapat menahan kemarahan, serta meningkatkan spiritualitas (Abdara \& Leila, 2016). Dengan munculnya berbagai efek tersebut maka memunculkan pertanyaan apakah dari berbagai efek positif tersebut terdapat hubungan antara tingkat kualitas puasa dengan kebahagiaan seseorang?

Beberapa penelitian mengenai puasa menunjukan adanya hubungan antara puasa dan kebahagiaan, Baroun menemukan korelasi positif yang signifikan di antara religiusitas, kesehatan, kebahagiaan kecuali untuk kecemasan, yang korelasinya negatif dan signifikan (Baroun, 2006).

Penelitian Abadi, Farid, Bahari dan Chami (2012) menunjukan bahwa terdapat perbedaan kecerdasan spiritual dan kebahagiaan pada orang yang berpuasa dan yang tidak berpuasa. Dimana subjek yang berpuasa memiliki kecerdasan spiritual dan kebahagiaan yang lebih tinggi daripada subjek yang tidak berpuasa karena alasan agama, dan subjek yang tidak berpuasa bukan karena alasan agama.

Hasil penelitian Mousavi, Seifi, Baghni dan Dolat (2016) menemukan adanya perbedaan positif yang signifikan antara level kebahagiaan sebelum dan sesudah puasa Ramadhan, masyarakat menemukan kebahagiaan dan relaksasi mental dengan adanya agama dan spiritualitas.

Penelitian Abdara dan Leila (2016) menunjukan adanya perbedaan fungsi mental yang signifikan antara sebelum dan sesudah puasa. Puasa Ramadhan memiliki nilai-nilai mistik, mempengaruhi kesehatan mental dengan mengurangi kebiasaan buruk sehari-hari. Ramadhan menjadikan orang-orang mempunyai ruh yang sedemikian rupa sehingga tetap bertahan dengan rasa lapar dan haus, tetap berinteraksi baik dengan masyarakat, dapat mengendalikan kemarahan, serta meningkatkan spiritualitas (Abdara \& Leila, 2016).
Amin, Kumar, Mishra Reddy, Sriams dan Mukkadan (2016) melakukan penelitian mengenai efek puasa selama bulan Ramadhan terhadap depresi, stress, dan kecemasan dari penelitian tersebut didapat hasil bahwa terdapat penurunan kecemasan yang signifikan, tingkat kognisi meningkat, dan terdapat dampak positif puasa pada depresi, kecemasan, stress, dan fungsi kognitif (Amin, Kumar, Mishra Reddy, Sriams \& Mukkadan, 2016).

Kualitas puasa berdasarkan pendapat AlGhazali dalam penelitian ini diambil dari tiga tingkatan puasa menurut Al-Ghazali. Imam AlGhazali membagi puasa menjadi tiga tingkatan yaitu puasa khusus, puasa umum dan puasa paling khusus (Al-Ghazali, 2012). Ketiga tingkatan tersebut merupakan konsep hierarki, sehingga untuk menempati posisi teratas maka seseorang harus dapat melewati tingkatan yang ada dibawahnya. Pada setiap fase terdapat kriteria-kriteria yang menjadi indikator tingkatan puasa yang dilihat melalui perilaku subjek, dimana kriteria tersebut merupakan indikasi-indikasi kualitas puasa.

Berdasarkan pemaparan di atas dapat disimpulkan efek dari puasa diantaranya:

1. Puasa meningkatkan regulasi kemarahan

2. Puasa berkorelasi dengan kemampuan pengendalian diri

3. Puasa berkorelasi dengan religiusitas, kesehatan dan kebahagiaan

4. Puasa meningkatkan kecerdasan spiritual dan kebahagiaan

5. Puasa menimbulkan kebahagiaan dan relaksasi mental

6. Puasa menimbulkan efek positif pada aspek mental dan sosial, berupa kemampuan untuk berinteraksi dengan baik dan kemampuan mengendalikan kemarahan

7. Puasa menurunkan depresi, stress dan cemas

Berdasarkan pemaparan yang telah dijelaskan sebelumnya, ditemukan berbagai efek positif dari puasa yang berpotensi menimbulkan emosi yang berhubungan dengan timbulnya kebahagiaan bagi individu yang melaksanakannya. 
Martin Seligman (2005), pendiri psikologi positif, mendefinisikan kehidupan yang baik sebagai "menggunakan kekuatan diri sendiri pada setiap waktu untuk menghasilkan kebahagiaan yang otentik dan berlimpah" (Compton \& Hoffman, 2013). Kebahagiaan merupakan konsep psikologis yang mengacu pada emosi positif yang dirasakan individu serta aktivitasaktivitas positif yang disukai oleh individuindividu tersebut (Seligman, 2005).

Argyle (2009) tidak menyebutkan secara tegas aspek-aspek dari kebahagiaan, namun peneliti mencoba mengabstraksikan aspekaspek kebahagiaan dari berbagai tulisan Argyle. Aspek-aspek tersebut diantaranya: frekuensi dan derajat emosi positif, level rata-rata kepuasan pada suatu periode, dan hilangnya emosi negatif.

Berdasarkan permasalahan tersebut peneliti bermaksud melakukan penelitian untuk mengetahui apakah terdapat hubungan antara kualitas puasa dengan kebahagiaan santri Pondok Pesantrel Al-Ihsan. Hasil penelitian ini diharapkan dapat membantu memberikan masukan informasi dan gambaran tentang tingkatan puasa dan kebahagiaan yang dimiliki oleh para santri, hasil penelitian ini juga acuan bagi orangtua untuk mempertimbangkan pendidikan yang sesuai dengan anaknya, serta diharapkan puasa dapat menjadi alternatif model psikoterapi yang bisa dilakukan secara mandiri, serta memotivasi umat Islam khususnya untuk senantiasa konsisten menjalankan puasa baik puasa wajib maupun puasa sunnah. Dengan hipotesis yang diajukan peneliti yaitu "terdapat hubungan kualitas puasa terhadap kebahagiaan santri Pondok Pesantren AlIhsan.”

\section{Metode}

\section{Variabel Penelitian}

Pada penelitian ini terdapat dua variabel yakni variabel $\mathrm{x}$ dan variabel $\mathrm{y}$.

\section{Variabel $x$ : tingkatan kualitas puasa}

Definisi konseptual. Makna kualitas puasa adalah tingkat kulitas puasa berdasarkan tingkatan puasa yang terdiri dari puasa umum, puasa khusus dan puasa paling khusus (AlGhazali, 2012)

Definisi operasional. Kualitas puasa adalah tingkat dimana seseorang melakukan puasa dengan tingkatan menghindari makan dan minum serta melakukan hubungan seksual (puasa awam), puasa dengan menjaga seluruh indera dari perbuatan dosa dan maksiat (puasa khusus), dan puasa dengan mengendalikan qalbu serta pikiran hanya tertuju kepada Allah (puasa tingkatan yang spesial). Kualitas puasa diukur dengan menggunakan skala tingkat kualitas puasa.

\section{Variabel y: kebahagiaan}

Definisi konseptual. Michael Argyle menyatakan bahwa kebahagiaan merupakan hasil dari pengalaman yang dipengaruhi oleh tiga hal, yakni kepuasan dalam kehidupan, munculnya emosi positif dan tidak adanya emosi negatif (Argyle, 2009).

Definisi operasional. Kebahagiaan yaitu emosi dan kepuasan yang dirasakan individu ketika berpuasa. Kebahagiaan diukur dengan menggunakan skala Oxford happiness Questionare (OHQ) yang dibuat oleh Peter Hills dan Michael Argyle (2001). Oxford happiness Questionare merupakan pengembangan dari Oxford Happiness Inventory (OHI) yang dibuat oleh Argyle dan Lu (1990) yang didasarkan pada kepuasan dalam kehidupan, munculnya emosi positif dan tidak adanya emosi negatif.

\section{Subjek Penelitian}

Pemilihan subjek pada pebelitian ini didasarkan pada beberapa kriteria, yaitu:

1. Santri Pondok Pesantren Al-Ihsan

2. Santri putera dan puteri

3. Pernah melaksanakan puasa

Populasi penelitian ini yaitu seluruh santri yang aktif di pesantren yang berjumlah 600 orang. Karena jumlah populasi terlalu besar, peneliti melakukan penelitian pada sampel dengan jumlah sampel dari populasi antara 25$30 \%$ (150 orang) dari jumlah subjek tersebut (Arikunto, 2005). 


\section{Teknik Pengumpulan Data}

Teknik pengumpulan data yang digunakan dalam penelitian ini adalah dengan cara membagikan questioner.

Instrument penelitian. Instrumen penelitian yang digunakan berupa skala linkert, dengan gradasi jawaban 1 sampai 6 (Sangat Sangat Tidak Sesuai sampai Sangat Sangat Sesuai).

Skala tingkat kualitas puasa. Alat ukur tingkat kualitas puasa diambil dari tingkatan puasa menurut Al-Ghazali (2012) yang mengacu pada tiga indikator yang dibuat oleh (Puspasari \& Gamayanti, 2016).

Skala kebahagiaan. Alat ukur yang digunakan dalam penelitian ini diambil dari Oxford Happiness Questioner dari Hills dan Argyle (2002).

Analisis item. Untuk menguji instrument yang telah digunakan, peneliti melakukan uji coba terhadap alat ukur yang akan digunakan. Dengan prosedur analisis item menggunakan confirmatory factor analysis dengan menggunakan software Lisrel versi 8.7, dengan nilai standardized loading $>0.5$. Berdasarkan hasil analisis item menunjukan bahwa terdapat dua indikator yang hilang hal ini kemungkinan terjadi karena beberapa hal, sehingga konstruk dari variabel kualitas puasa tidak sepenuhnya sama dengan teori yang telah dipaparkan sebelumnya. Indikator yang hilang yakni indikator tidak melakukan aktiftas seksual dan indikator sosok yang produktif sehingga kedua indikator tersebut tidak dapat tergali dari pengambilan data secara kuantitatif. Hal ini dapat disebabkan, diantaranya kualitas item yang belum mampu mengukur indikator yang dimaksud, item tersebut tidak dapat menggambarkan kondisi subjek, serta adanya kemungkinan subjek mengisi dengan asal. Perlu dilakukan penelitian lebih lanjut untuk mengetahui hal tersebut, dalam penelitian ini peneliti tidak melakukan penelaahan lanjutan tersebut. Selanjutnya peneliti menggunakan faktor-faktor yang ada untuk menyusun skala kualitas puasa yang akan digunakan dan kemudian melakukan wawancara untuk meng- gali aspek-aspek yang tidak dapat diketahui melalui angket.

Pengujian variabel kebahagiaan dilakukan melalui komputasi koefisien korelasi antara distribusi skor item satu dengan kriteria yang relevan, yaitu distribusi skor skala itu sendiri. Untuk kriteria pemilihan item, digunakan batasan $r_{i x} \geq 0.3$. Untuk skala kebahagiaan dari 29 item terdapat 10 item yang baik dengan skor $\geq 0.3$ dan 20 item yang buruk dengan skor $<$ 0.3 .

Uji validitas. untuk variabel kualitas puasa uji validitas menggunakan uji Fit di yang dilakukan dengan menggunakan software Lisrel versi 8.7 dan untuk variabel kebahagiaan perhitungannya menggunakan korelasi product moment pearson yang diolah menggunakan program komputer.

Dalam analisis faktor konfirmatori data dikatakan valid ketika data tersebut fit, adapun kriteria fit ditentukan oleh adanya minimal 3 kriteria dari kriteria berikut: RMSEA $<0.08$, $\mathrm{X}^{2}>0.05, \mathrm{GFI}>0.9, \mathrm{NFI}>0.9, \mathrm{NNFI}>0.9, \mathrm{CFI}$ $>0.9$.

Berdasarkan uji validitas skala kualitas puasa dengan menggunakan confirmatory factor analysis didapat 3 kriteria uji Fit yaitu nilai RMSEA, GFI dan CFI sehingga model skala kualitas puasa dinyatakan Fit (cocok) atau valid untuk digunakan.

Uji validitas untuk skala kebahagiaan dalam penelitian ini menggunakan korelasi product moment pearson. Interpretasi hasil uji validitas dilakukan dengan membandingkan hasil uji validitas dengan nilai koefisien korelasi tabel (Somantri, 2011). Dalam penelitian ini kriteria validasi menurut Guilford.

Berdasarkan hasil uji validitas dengan metode korelasi terhadap skala kebahagiaan maka diperoleh hasil sebagai berikut:

Tabel 1. Hasil Uji Korelasi Skala Kebahagiaan

\begin{tabular}{lll}
\hline Dimensi & Korelasi & Keterangan \\
\hline Emosi positif & 0.761 & Hubungan kuat \\
Satisfaction & 0.773 & Hubungan kuat \\
Emosi negatif & 0.532 & $\begin{array}{l}\text { Hubungan } \\
\text { sedang / cukup }\end{array}$ \\
\hline
\end{tabular}


Berdasarkan tabel 1, korelasi pada skala kebahagiaan menunjukan nilai yang cukup dan kuat, ini menunjukan derajat validitas yang baik, sehingga alat ukur kebahagiaan ini dapat dinyatakan valid atau mengukur apa yang akan di ukur.

Uji reliabilitas. Pada skala kualitas puasa, penghitungan reliabilitas digunakan dengan menghitung reliabilitas contruct reliability dan variance extract, adapun rumus yang digunakan yaitu sebagai berikut.

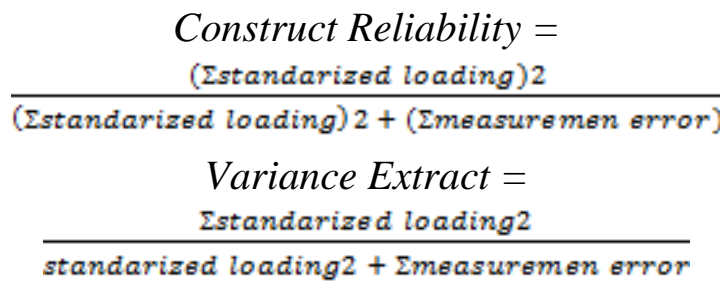

Keterangan:

Standardized loading : nilai faktor loading setiap item yang sudah terseleksi yaitu yang nilainya diatas 0.5 .

Measuremen eror : 1-nilai faktor loading item.

Nilai construct reliability yang diharapkan adalah $>0.70$ dan variance extract $>0.50$ berdasarkan hasil penghitungan Construct reliability alat ukur reliabel karena nilainya $0.87(>0.70)$ dan variance extract tidak reliabel karena nilainya $0.42(<0.50)$. Dalam penelitian ini untuk skala kebahagiaan penghitungan reliabilitas menggunakan metode cronbach alpha reliability. Berdasarkan uji reliabilitas yang telah dilakukan didapat nilai reliabilitas kebahagiaan yaitu 0.772 (reliabel).

\section{Teknik Analisis Data}

Peneliti menggunakan analisis deskriptif untuk mengetahui gambaran tingkat kualitas puasa dan kebahagiaan santri. Lalu dilakukan teknik analisis inferensial. Pada penelitian ini digunakan analisis data dengan analisis korelasi Pearson, yakni untuk mengetahui atau mencari hubungan antara dua fenomena, baik asosiasi sejajar maupun hubungan kausal, kerangka analisisnya menjurus pada usaha menguji ada tidaknya hubungan antara dua variabel atau lebih (Sugiyono, 2012). Peneliti juga melakukan uji normalitas dengan menggunakan uji Kolmogorov Smirnov.

\section{Hasil}

\section{Analisis deskriptif}

Untuk mengetahui hubungan tingkat kualitas puasa dan kebahagiaan santri, maka dilakukan analisis deskriptif berupa pembuatan kategorisasi tingkat kualitas puasa dan kebahagiaan. Sebelum dikategorisasi, data diolah dengan method of succesive interval (MSI) untuk mengubah data ordinal ke interval. Adapun hasil analisis deskriptif dari skala tingkat kualitas puasa dan skala kebahagiaan, yaitu sebagai berikut.

Tabel 2. Hasil Analisis Deskriptif Skala Tingkat Kualitas Puasa dan Skala Kebahagiaan

\begin{tabular}{llll}
\hline & & Puasa & Kebahagiaan \\
\hline $\mathrm{N}$ & Valid & 150 & 150 \\
& Missing & 0 & 0 \\
Mean & & 99.4252 & 31.1990 \\
Median & & 98.5465 & 30.7010 \\
Mode & & $103.91^{\mathrm{a}}$ & 30.39 \\
Std. Deviation & 16.45806 & 5.56101 \\
Minimum & & 70.17 & 20.66 \\
Maximum & & 167.84 & 81.01 \\
Sum & & 14913.78 & 4679.84 \\
Percentiles & 25 & 87.7953 & 28.3990 \\
& 50 & 98.5465 & 30.7010 \\
& 75 & 106.2660 & 32.9283 \\
\hline
\end{tabular}

Berdasarkan tabel 2 diketahui bahwa pada skala tingkat kualitas puasa nilai mean sebesar 99,4252 dengan nilai median 98,5465 dan nilai standar deviasi 16,4581 . Sedangkan pada skala kebahagiaan didapat nilai mean 31,1990 dengan nilai median 30,7010 dan nilai standar deviasi 5,5610 .

Kategorisasi tingkatan kualitas puasa dan tingkatan kebahagiaan dibagi menjadi tiga kategori, yakni kategori rendah, sedang dan tinggi, hal ini karena data berbentuk interval. Adapun berdasarkan hasil perhitungan yang telah dilakukan didapat hasil sebagai berikut. 
Dari 150 responden penelitian, terdapat $14 \%$ yang berjumlah 21 responden memiliki tingkat kualitas puasa tinggi, dan $71,33 \%$ yang berjumlah 107 responden memiliki tingkat kualitas puasa sedang, serta $14,67 \%$ yang berjumlah 22 responden memiliki tingkat kualitas puasa rendah. Berdasarkan hasil tersebut diketahui bahwa variabel tingkat kualitas puasa pada responden berada pada tingkat yang sedang.

Dari 150 responden penelitian, terdapat $6,67 \%$ yang berjumlah 10 responden memiliki tingkat kebahagiaan tinggi, dan $88 \%$ yang berjumlah 132 responden memiliki tingkat kebahagiaan sedang, serta $5,33 \%$ yang berjumlah 8 responden memiliki tingkat kebahagiaan rendah. Berdasarkan hasil tersebut diketahui bahwa variabel kebahagiaan pada responden berada pada tingkat yang sedang.

Setelah mengetahui tingkat kualitas puasa dan kebahagiaan santri, dibuat distribusi silang dengan menyatukan hasil kategorisasi pada aspek tingkat kualitas puasa dan aspek kebahagiaan, adapun hasilnya yaitu sebagai berikut.

Berdasarkan hasil distribusi silang skala tingkat kualitas puasa dan kebahagiaan, yaitu responden dengan tingkat kualitas puasa tinggi dan kebahagiaan tinggi berjumlah 4 responden, responden dengan tingkat kualitas puasa tinggi dan kebahagiaan sedang berjumlah 17 responden, tidak ada responden dengan tingkat kualitas puasa tinggi dan kebahagiaan rendah, responden dengan tingkat kualitas puasa sedang dan kebahagiaan tinggi sejumlah 6 responden, responden dengan tingkat kualitas puasa sedang dan kebahagiaan sedang sejumlah 98 responden, responden dengan tingkat kualitas puasa sedang dan kebahagiaan rendah sejumlah 3 responden, tidak terdapat responden dengan tingkat kualitas puasa rendah dan kebahagiaan tinggi, responden dengan tingkat kualitas puasa rendah dan kebahagiaan sedang sejumlah 17 responden dan responden dengan tingkat kualitas puasa rendah dan kebahagiaan rendah sejumlah 5 responden. Jadi mayoritas responden memiliki tingkat kualitas puasa dan kebahagiaan sedang.

Subjek penelitian ini terdiri dari 39 orang laki-laki dengan presentase $26 \%$ dan 111 orang subjek perempuan dengan presentase $74 \%$. Berdasarkan jenis kelamin subjek, terdapat perbedaan kualitas puasa dan kebahagiaan pada subjek laki-laki dan subjek perempuan. Ratarata skor pada subjek laki-laki yaitu, skor kualitas puasa 37.359 dan skor rata-rata kebahagiaan yaitu 41.461 .

Sementara itu, rata-rata skor pada subjek perempuan yaitu, skor kualitas puasa 35.595 dan skor rata-rata kebahagiaan yaitu 40.955. Sehingga dapat disimpulkan bahwa skor tingkat kualitas puasa dan kebahagiaan pada subjek laki-laki lebih tinggi daripada subjek perempuan.

\begin{tabular}{lcc}
$\begin{array}{c}\text { Tabel 3. Skor Rata-Rata Kualitas Puasa dan } \\
\text { Kebahagiaan Berdasarkan Jenis } \\
\text { Kelamin }\end{array}$ & \\
\hline \multicolumn{1}{c}{ Jenis Kelamin } & $\begin{array}{c}\text { Kualitas } \\
\text { Puasa }\end{array}$ & Kebahagiaan \\
\hline Laki-Laki & 37.359 & 41.461 \\
Perempuan & 35.595 & 40.955 \\
\hline
\end{tabular}

Tabel 3 menunjukkan bahwa rata-rata skor kualitas puasa laki-laki (37.359) > rata-rata skor kualitas puasa perempuan (35.595) dan ratarata skor kebahagiaan laki-laki (41.461) > ratarata skor kebahagiaan perempuan (40.955). Jadi dapat disimpulakan bahwa skor tingkat kualitas puasa dan kebahagiaan pada subjek laki-laki lebih tinggi daripada subjek perempuan.

\section{Statistik Inferensial}

Uji normalitas.Uji normalitas dilakukan untuk melihat data penelitian normal atau tidak. Uji normalitas ini dilakukan dengan menggunakan uji Kolmogorov Smirnov. Adapun hasil dari uji normalitas skala tingkat kualitas puasa dan kebahagiaan menunjukkan bahwa nilai signifikansi sebesar 0,337 lebih besar dari 0.05 , sehingga dapat disimpulkan bahwa data tersebut berdistribusi normal.

Uji korelasi. Variabel tingkat kualitas puasa dan kebahagiaan kemudian dikorelasikan 
dengan perhitungan menggunakan korelasi pearson. Hasil penghitungan uji korelasi pearson yaitu sebagai berikut:

Tabel 4. Hasil Uji Korelasi

Correlations

\begin{tabular}{llll}
\hline & & Puasa & \multicolumn{1}{c}{$\begin{array}{l}\text { Kebaha } \\
\text { giaan }\end{array}$} \\
\hline Puasa & Pearson & 1 & $.466^{* *}$ \\
& Correlation & & \\
& Sig. (2-tailed) & & .000 \\
& $\mathrm{~N}$ & 150 & 150 \\
Kebahagiaan & Pearson & $.466^{* *}$ & 1 \\
& Correlation & & \\
& Sig. (2-tailed) & .000 & \\
& $\mathrm{~N}$ & 150 & 150 \\
**. Correlation is significant at the 0.01 level (2- \\
tailed).
\end{tabular}

Dari tabel 4 diatas diketahui bahwa nilai korelasi yang didapat dari tingkatan kualitas puasa dan kebahagiaan yaitu 0,466 >0.05. maka diketahui bahwa dalam penelitian ini $\mathrm{H}_{1}$ diterima. Adapun hipotesis penelitian ini yaitu terdapat hubungan antara tingkat kualitas puasa dengan kebahagiaan santri pondok pesantren Al-Ihsan. Maka dapat disimpulkan bahwa dalam penelitian ini terbukti bahwa terdapat hubungan tingkat kualitas puasa dengan kebahagiaan santri pondok pesantren Al-Ihsan.

Untuk mengetahui korelasi antara setiap tingkat kualias puasa dengan kebahagiaan, dilakukan uji korelasi Pearson antara tingkatan puasa yaitu puasa umum, puasa khusus, dan puasa paling khusus dengan kebahagiaan.

Berdasarkan tabel 5 diketahui bahwa nilai korelasi aspek-aspek puasa dengan kebahagiaan yaitu, korelasi puasa umum dengan kebahagiaan 0.250 , korelasi puasa khusus dengan kebahagiaan 0.430 dan korelasi puasa paling khusus dengan kebahagiaan 0.450 . nilai korelasi dari seluruh aspek tingkat kualitas puasa dan kebahagiaan $>0.05$, hal ini menunjukan adanya korelasi dari setiap aspek tingkat kualitas puasa dengan kebahagiaan.
Tabel 5. Hasil Uji Korelasi Aspek-Aspek Tingkat Kualitas Puasa Dengan Kebahagiaan

Correlations

\begin{tabular}{|c|c|c|c|c|c|}
\hline & & $\begin{array}{l}\mathrm{P} \\
\text { umum }\end{array}$ & $\begin{array}{l}\mathrm{P} \\
\text { khusus }\end{array}$ & $\begin{array}{l}\mathrm{P} \\
\text { pkhusus }\end{array}$ & Bahagia \\
\hline \multirow{4}{*}{$\begin{array}{l}\mathrm{P} \\
\text { umum }\end{array}$} & Pearson & 1 & $.479^{* * *}$ & $.461^{* *}$ & $.250^{* * *}$ \\
\hline & $\begin{array}{l}\text { Correlati } \\
\text { on }\end{array}$ & & & & \\
\hline & $\begin{array}{l}\text { Sig. } \\
\text { (2-tailed) }\end{array}$ & & .000 & .000 & .002 \\
\hline & $\mathrm{N}$ & 150 & 150 & 150 & 150 \\
\hline \multirow{4}{*}{$\begin{array}{l}\text { P } \\
\text { khusus }\end{array}$} & Pearson & $.479^{* * *}$ & 1 & $.763^{\text {** }}$ & $.430^{* *}$ \\
\hline & $\begin{array}{l}\text { Correlati } \\
\text { on }\end{array}$ & & & & \\
\hline & $\begin{array}{l}\text { Sig. } \\
\text { (2-tailed) }\end{array}$ & .000 & & .000 & .000 \\
\hline & $\mathrm{N}$ & 150 & & 1150 & 150 \\
\hline \multirow{4}{*}{$\begin{array}{l}\text { P } \\
\text { pkhusus }\end{array}$} & Pearson & $.461^{* *}$ & $.763^{* *}$ & 1 & $.450^{* *}$ \\
\hline & $\begin{array}{l}\text { Correlati } \\
\text { on }\end{array}$ & & & & \\
\hline & $\begin{array}{l}\text { Sig. } \\
\text { (2-tailed) }\end{array}$ & .000 & .000 & & .000 \\
\hline & $\mathrm{N}$ & 150 & 150 & 150 & 150 \\
\hline \multirow[t]{3}{*}{ Bahagia } & $\begin{array}{l}\text { Pearson } \\
\text { Correlati } \\
\text { on }\end{array}$ & $.250^{* * *}$ & $.430^{* * *}$ & $.450^{* * *}$ & 1 \\
\hline & $\begin{array}{l}\text { Sig. } \\
\text { (2-tailed) }\end{array}$ & .002 & .000 & .000 & \\
\hline & $\mathrm{N}$ & 150 & 150 & 150 & 150 \\
\hline
\end{tabular}

\section{Diskusi}

Berdasarkan hasil pengolahan data diketahui bahwa hipotesis penelitian ini diterima yaitu terdapat hubungan antara kualitas puasa dan kebahagiaan santri pondok pesantren Al-Ihsan, dengan nilai korelasi 0,466 yang berdasarkan tabel korelasi Guilford, korelasi antara tingkat kualitas puasa dan kebahagiaan ini mempunyai korelasi sedang.

Secara umum adanya hubungan kualitas puasa terhadap kebahagiaan ini mendukung hasil penelitian Abadi, Farid, Bahri dan Chaimi (2012) yang menyatakan bahwa puasa orang Islam dapat menimbulkan kecerdasan spiritual dan kebahagiaan. Hasil penelitian ini juga sesuai dengan hasil penelitian Mousavi, Seifi, Bahgni dan Dollat (2015) yang berkesimpulan bahwa puasa memiliki efek positif terhadap level kebahagiaan. 
Pada konsep puasa menurut Al-Ghazali, puasa terbagi menjadi tiga tingkatan yakni puasa umum, puasa khusus dan puasa paling khusus. Pada individu yang ada dalam tingkatan puasa umum ia dapat mengendalikan diri dari makan dan minum serta aktivitas seksual, Namun dalam penelitian ini, saat dilakukan uji coba alat ukur, alat ukur yang telah dibuat tidak menggambarkan adanya aspek aktivitas seksual pada saat santri yang berpuasa, dari data 209 responden mayoritasnya memberi jawaban tengah-tengah untuk item yang menggambarkan aspek seksual. Hal tersebut dapat diakibatkan oleh kondisi santri yang secara pengetahuan santri telah mengetahui bahwa pada saat berpuasa individu harus benar-benar menghindari perilaku yang dapat menimbulkan syahwat, ataupun karena santri merasakannya tapi hal ini berbenturan dengan norma yang telah diketahui jadi ketika hal tersebut ditanyakan, maka jawaban-jawaban yang muncul cenderung normatif.

Untuk melengkapi data mengenai aspek aktivitas seksual, peneliti melakukan wawancara terhadap 8 subjek yang terdiri dari 7 orang perempuan dan 1 orang laki-laki. Berdasarkan hasil wawancara diketahui bahwa santri tidak melakukan aktivitas seksual ketika berpuasa, ketika subjek memiliki kecenderungan suka terhadap lawan jenispun subjek cenderung berusaha mengalihkan perasaannya dengan cara memperbanyak aktivitas yang menyibukan serta berusaha untuk tidak banyak berinteraksi langsung dengan lawan jenis yang disukai. Hal ini karena subjek mengetahui bahwa ketika puasa diharuskan untuk menjaga diri dari halhal yang menimbulkan syahwat dan kecenderungan untuk melakukan aktivitas seksual. Bagi subjek yang mempunyai pasangan (pacar) juga tidak melakukan hal-hal yang berupa aktivitas seksual, ada kesadaran bahwa subjek sedang berpuasa sehingga subjek lebih berusaha untuk mengendalikan dirinya.

Ketika subjek melihat orang lain berpegangan tangan ataupun berdekatan dengan lawan jenis, subjek merasa risih dan jika orang tersebut adalah orang yang dikenal maka subjek berusaha untuk menasehatinya. Subjek berusaha untuk tidak menonton hal-hal yang mengandung adegan aktivitas seksual, namun dalam hal ini ketika yang ditonton misalnya adegan berpegangan tangan subjek masih bisa memakluminya. Subjek langsung memindahkan saluran televisi atau mempercepat tanyangan yang ditontonnya jika memperlihatkan adegan aktivitas seksual.

Kemampuan mengendalikan diri dari aktivitas seksual pada subjek karena subjek mengetahui bahwa ketika puasa subjek diharuskan untuk mampu menahan syahwat, dan hal ini juga didukung oleh lingkungan pesantren dimana antara asrama laki-laki dan perempuan terpisah, sehingga ada keterbatasan untuk berinteraksi dengan lawan jenis, hal ini membuat subjek lebih bisa mengendalikan syahwatnya terhadap lawan jenis.

Tingkatan puasa yang kedua yaitu puasa khusus, dimana puasa khusus diukur berdasarkan indikator menjaga alat indra dari pelanggaran syari'at, menampilkan perilaku yang sabar dan menjadi sosok yang produktif. Indikator menjadi sosok yang produktif tidak tergambarkan oleh alat ukur kualitas puasa yang telah dibuat, hal ini dapat terjadi karena ketika puasa santri cenderung meminimalisir kegiatannya, menurut hasil observasi peneliti, kegiatankegiatan rutin seperti pengajian dikurangi jadwalnya dari awalnya 4 kali dalam sehari menjadi 2 kali oleh pihak pesantren, jamaah solat maghrib juga berkurang secara drastis, serta minimnya kegiatan yang dilakukan oleh organisasi santri yang ada di pesantren, ketika ada kegiatanpun santri yang ikut berpartisipasi aktif baik sebagai peserta maupun panitia hanya sedikit.

Tingkat puasa yang ketiga yakni puasa paling khusus yang digambarkan melalui indikator mengosongkan hati dari selain Allah dan bahagia ketika berperilaku sesuai dengan kehendakNya. Kedua hal ini dapat terhambarkan oleh alat ukur yang digunakan.

Hal yang menarik bagi peneliti adalah bahwa pada diri santri tergambarkan indikator yang menunjukan bahwa santri dapat 
mengosongkan hati dari kehendak pribadi serta bahagia ketika berperilaku sesuai dengan kehendak Allah, yang berarti bahwa santri melakukan berbagai hal atas pertimbangan kesesuaian perilakunya dengan perilaku yang diinginkan oleh Allah. Namun sisi produktivitasnya tidak muncul, jika dikaitkan dengan pendapat Al-Ghazali, seharusnya orang yang berperilaku sesuai dengan kehendak Allah akan menunjukannya dengan berbagai aktivitas produktif yang bisa dilakukan ketika sedang berpuasa, terutama bagi subjek yang merupakan santri, secara keilmuan subjek dianggap telah mengetahui bahwa meningkatkan produktivitas ibadah dan berbuat baik pada saat puasa akan menambah kualitas puasanya.

Untuk menggali aspek produktivitas ketika puasa dilakukan wawancara terhadap 8 subjek, berdasarkan hasil wawancara diketahui bahwa ketika puasa subjek merasakan lemas saat beraktivitas, terkadang menunda untuk melakukan suatu pekerjaan dan ada pengalihan waktu untuk pekerjaan berat yang biasanya dilakukan di siang hari di pindahkan ke pagi atau sore hari. Ketika puasa kuantitas kegiatan berkurang, hal ini karena subjek melakukan pemilihan untuk melakukan aktivitas yang perlu dilakukan saja, subjek cenderung tidak melakukan hal-hal yang kurang bermanfaat untuk menjaga energinya, namun secara umum subjek masih dapat beraktivitas dengan baik, kualitas pekerjaan subjek ketika puasa juga tetap baik, dan pada beberapa subjek hasil pekerjaannya lebih baik daripada pada hari-hari biasa.

Adanya pengurangan aktivitas ini merupakan usaha untuk menghemat energi, subjek lebih fokus pada pekerjaan yang penting dan tidak melakukan hal-hal yang tidak penting, hal ini diduga menjadi penyebab hasil pekerjaan beberapa subjek yang sedang puasa lebih baik daripada ketika tidak berpuasa.

Selain itu hal menarik lain dari penelitian ini yaitu, bahwa berdasarkan data yang diperoleh diketahui tingkat kualitas puasa dan kebahagiaan pada subjek laki-laki lebih tinggi daripada subjek perempuan, dimana hal ini bertentangan dengan beberapa penelitian yang pernah dilakukan sebelumnya seperti pada penelitian Hvidtjorn, Hjelmborg, Skytthe, Christensen dan Hvidt (2013) yang meneliti religiusitas pada 3.000 masyarakat sekuler Denmark menunjukan bahwa perempuan lebih religious daripada laki-laki dan lebih berpotensi menggunakan koping dengan agama.

Chui dan Wong (2015) meneliti hubungan perbedan gender pada kebahagiaan dan kepuasan hidup remaja akhir di Hongkong menyatakan bahwa siswa laki-laki menunjukan performance akademik dan prestasi belajar yang lebih rendah dimana hal tersebut merupakan salah satu indikator kesejahteraan individu. Sedangkan subjek perempuan memiliki tujuan hidup dan kepuasan akademik yang lebih tinggi sehingga cenderung lebih bahagia. Selain itu seorang laki-laki dinyatakan kurang bahagia ketika memasuki masa remaja akhir.

Berdasarkan data yang diperoleh, menunjukan bahwa puasa berhubungan dengan kebahagiaan, hal ini dapat terjadi ketika santri dapat menghayati makna dari puasa tersebut, tidak hanya menjalankan puasa secara lahiriyah seperti menahan makan dan minum, namun telah masuk pada aspek batiniyahnya seperti tidak membayangkan makanan yang ia sukai, tidak dengan sengaja melihat gambar-gambar makanan sebagai kompensasi karena ia tidak makan serta tidak memikirkan apa yang ingin di makan pada saat buka dan sahur.

Kualitas puasa yang tinggi juga ditunjukan dengan kemampuan menjaga indera dari dosa dan menunjukan perilaku yang sabar, hal ini berarti ketika puasa, santri mampu mengontrol dirinya, baik dari segi perkataan yakni dengan hanya mengatakan hal-hal yang baik, tidak marah-marah, tidak ngomel dan sebagainya, mengontrol penglihatan dari melihat hal yang dilarang, seperti film porno dan melihat lawan jenis dengan syahwat, serta menunjukan sikap sabar, baik sabar dalam menghadapi masalah perkuliahan, masalah organisasi, serta mampu untuk senantiasa menjalankan kewajiban di pondok.

Santri dengan kualitas puasa yang tinggi melakukan sesuatu sesuai kehendak Allah, saat 
akan melakukan sesuatu ia senantiasa penuh perhitungan, ia berusaha menyelaraskan apa yang ia akan lakuakan dengan kehendak tuhannya, baik dalam hal beribadah maupun dalam hal berbuat baik pada manusia. Dalam hal ibadah, ia melakukannya denga sungguhsungguh karena perasaan takut dan berharapnya pada Allah. Seligman (2005) yang menyatakan bahwa agama mengisi manusia dengan harapan akan masa depan dan menciptakan makna dalam hidup seseorang, ia akan merasakan optimisme, harapan, keyakinan dan kepercayaan. Joshalo (2012) memperkuat asumsi ini dengan berpendapat bahwa kebahagiaan dalam Islam itu mencakup kepuasan dari ibadahnya dan kebahagiaannya meliputi kebahagiaan dunia dan akhirat.

Santri dalam penelitian ini mayoritas mendapatkan nilai kualitas puasa dan kebahagiaan yang sedang, dengan adanya hubungan kualitas puasa terhadap kebahagiaan menunjukan bahwa santri yang kualitas puasanya lebih tinggi dapat memiliki kebahagiaan yang lebih tinggi pula, hal tersebut karena ketika sedang berpuasa santri menjadi santri yang dapat menjaga diri dari melakuan hal-hal yang negatif seperti berbohong, marah, melihat sesuatu yang menimbulkan syahwat, tidak mendengar dan tidak melakukan hal-hal buruk, sehingga santri bisa menghindari kemungkinan untuk merasakan emosi negatif. Santri juga menunjukan perilaku yang sabar dan ketika melalukan suatu hal hanya didasarkan pada kehendak Allah, meskipun dalam penelitian ini aspek produktivitasnya tidak terlihat.

Adapun pada sebagian santri yang kualitas puasa dan kebahagiaannya rendah kemungkinan ada bagian dari kebahagiaan yang belum terpenuhi oleh santri, misalnya santri masih merasakan emosi negatif karena belum bisa menjaga dirinya dari melakukan hal-hal negatif, seperti mengeluh, marah-marah, ngomel, ketika puasa maka hal tersebut akan membuat santri merasakan emosi negatif dan tidak mampu merasakan kebahagiaan. Santri juga kemungkinan tidak puas dengan kehidupannya saat ini, hal ini karena dengan tinggal di pondok pesantren santri harus berbagi fasilitas dengan santri lainnya, seperti kamar tidur dan kamar mandi yang dipakai oleh banyak orang sehingga privasi setiap orang kurang terjaga, hal ini juga dapan membuat santri memiliki kebahagiaan yang rendah.

\section{Simpulan}

Berdasarkan hasil analisis data dan pengujian hipotesis diketahui bahwa hipotesis peneliti dapat diterima, hal ini menunjukan bahwa terdapat hubungan tingkat kualitas puasa dan kebahagiaan pada santri pondok pesantren Al-Ihsan, dengan hubungan kualitas puasa terhadap kebahagiaan yang positif yaitu 0,466 yakni berada pada korelasi sedang. Santri pondok pesantren Al-Ihsan mayoritas memiliki tingkat kualitas puasa sedang dengan persentase $71,33 \%$ dari jumlah responden dan tingkat kebahagiaan sedang dengan presentase 88\% dari jumlah responden serta presentase santri yang memiliki tingkat kualitas puasa sedang dan tingkat kebahagiaan sedang 65,3\% dari jumlah responden.

Hasil penelitian ini menunjukkan bahwa jika skor kualitas puasa meningkat, yang di tandai dengan meningkatnya kemampuan mengendalikan diri dari makan dan minum serta hal-hal yang mendatangkan syawat, meningkatnya kemampuan menjaga alat indra dari pelanggaran syari'at serta menampilkan perilaku yang sabar dan menjadi sosok yang produktif, serta meningkatnya kemampuan untuk mengosongkan hati dari selain Allah dan bahagia ketika berperilaku sesuai dengan kehendak-Nya, maka meningkat pula skor kebahagiaan santri. Dari 150 responden penelitian, diperoleh bahwa rata-rata responden memiliki tingkatan yang sedang untuk kualitas puasa dan kebahagiaan dengan rata-rata kualitas puasa dan kebahagiaan laki-laki lebih tinggi daripada perempuan. Hasil skor kualitas puasa pada santri ini dikarenakan beberapa hal yaitu, santri dapat merasakan penghayatan makna dari puasa tersebut, tidak hanya menjalankan puasa secara lahiriyah seperti menahan makan dan minum, namun telah masuk pada aspek 
batiniyahnya, santri juga mampu menjaga indera dari dosa dan menunjukkan perilaku yang sabar, serta santri senantiasa berusaha melakukan sesuatu sesuai kehendak Allah, saat akan melakukan sesuatu ia senantiasa penuh perhitungan, ia berusaha menyelaraskan apa yang ia akan lakukan dengan kehendak Tuhannya, baik dalam hal beribadah maupun dalam hal berbuat baik pada manusia.

\section{Saran}

Untuk peneliti selanjutnya diharapkan dapat mengembangkan skala tingkat kualitas puasa dengan cara merekonstruksi teori, memperbanyak item, mengujinya kembali dengan teknik analisis yang lebih baik, serta mengujikan kepada subjek yang lebih banyak. Memperluas bidang penelitian tentang puasa pada berbagai setting. Meneliti kembali pengaruh kualitas puasa dengan berbagai variabel lain, baik yang berhubungan maupun yang mempengaruhi variabel tingkat kualitas puasa. Variabel kebahagiaan dapat dikembangkan dengan skala lain, sebaiknya dengan skala yang dikembangkan dari konsep kebahagiaan dalam Islam. Variabel kebahagiaan dapat menggunakan pengukuran lain selain puasa, misalnya sholat, sedekah, atau ibadah-ibadah yang lain.

\section{Referensi}

Abadi, Farid, Bahari \& Chami (2012). The effect of Islamic fasting in quran on spiritual intelligence and happiness of fasting persons. Quran Med, 1(3), 66-70. DOI: 10.5812/Quranmed.8030.

Abdara \& Leila. (2016). Analyzing the effects of the Ramadan on the mental and social aspects of Kerman's University of medical sciences' personnel. Journal of Europe-Revue Litteraire Mensuelle, 578-582.

Al-Ghazali. (2012). Ihya ulumuddin jilid 2. Jakarta: Republika.

Amin, K., Mishra R., Sriams, \& Mukkadan. (2016). Effects of fasting during ramadan month on depression, anxiety and stress and cognition. International Journal of Medical Research and Review, 40(5), 771-774.

Ardiansyah, A. (2014). Hubungan antara dukungan sosial teman sebaya dengan kebahagiaan pada mahasiswa. Skripsi. Fakultas Psikologi, Universitas Islam Negeri Sultan Syarif Kasim Pekanbaru. Argyle, M. (2009). Psychology of happiness (2nd ed). New York: Routledge.

Arikunto, S. (2005). Manajemen penelitian. Jakarta: Rineka Cipta.

Baround, K.A. (2006). Relations among religiosity, health, happiness, and anxiety for Kuwaiti adolescents. Journal of Psychological Reports,717-722.

Chui, W.H. \& Wong, M. (2015). Gender differences in happiness and life satisfaction among adolescents in Hong Kong: Relationship and self-concept. Springer Soc Indic Res.

Compton, C.C. \& Hoffman, E. (2013). Positive psychology: The science of happiness and flourishing. Canada: Cengage Learning.

Hills, P \& Argyle, M. (2002). The Oxford Happiness Questionnaire: A compact scale for the measurement of psychological well-being. Personality And Individual Differences, 33, 10731082.

Hvidtjorn, D. Hjelmborg, J. Skytthe, A. Christensen, K. \& Hvid, N.C. (2014). Religiousness and religious coping in a secular society: The gender perspective. epidemiology unit. $J$ Relig Health, 53(5), 1329-41. DOI: 10.1007/s10943013-9724-Z

Joshanloo, M. (2012). A comparison of western and islamic conception of happiness. $J$ Happiness Stud, 14, 1857-74. DOI: 10.1007/s10902-012-9406-7

Megarani. (2010). Strategi pemberdayaan santri di Pondok Pesantren Hidayatullah Donoharjo Ngaglik Sleman Yogyakarta. Skripsi. 
Yogyakarta: Fakultas Dakwah UIN Kalijaga Yogyakarta.

Mousavi, Seifi, Baghni, \& Dolat. (2015). The effect of fasting on the level of happiness general population of Kermanshan, Iran. Journal of Fasting and Health, 3(1). 29-54.

Qardawi, Y. (2006). Fiqih puasa. Surakarta: Era Intermedia.

Rosita, C.H. (2009). Puasa dan pengendalian diri perspektif kesehatan mental Skripsi. Yogyakarta: Universitas Islam Negeri Sunan Kalijaga.
Seligman, M.E.P. (2005). Authentic happiness (Alih Bahasa oleh Eva Yulia Nukman). Bandung: Mizan.

Somantri, A. (2011). Aplikasi statistika dalam penelitian. Jakarta: Pustaka Setia.

Subandi, M.A. (2009). Psikologi dzikir. Yogyakarta: Pustaka Belajar.

Sugiyono. (2012). Metode penelitian kuantitatif kualitatif dan $R \quad \& \quad D$. Bandung: Alfabeta.

Utami, Ms. (2009). Keterlibatan dalam kegiatan dan kesejahteraan subjektif mahasiswa. Jurnal Psikologi, 36(2), 144-163. DOI: https://doi.org/10.22146/jpsi.7892 
HUBUNGAN KUALITAS PUASA DAN KEBAHAGIAAN SANTRI PONDOK PESANTREN AL-IHSAN 